\title{
STIMULATION OF RED-CELL PRODUCTION IN MYELOFIBROSIS WITH PREDNISOLONE
}

\author{
C. D. R. Pengelly, M.D.(Brist.), M.R.C.P., M.R.C.P.E. \\ Consultant Physician, North and Mid Cheshire Hospitals; Honorary Research Worker in Hamatology, Manchester Ro R $l$ \\ Infirmary
}

Patients with myelofibrosis are usually treated with repeated blood transfusions and occasionally with busulphan or by splenectomy (Britton, I963). Splenic irradiation is sometimes of value (Szur and Smith, 1961). Adrenocorticosteroids are mentioned only in connection with the control of thrombocytopenia by Britton (1963), while Wintrobe (r96r) states that they are useless. Others, however, have found them of value in patients with excessive hæmolysis (Bowdler and Prankerd, 196r; Gardner and Pringle, 196r). Androgens have been shown to increase red-cell production (Gardner and Pringle, I96I), and so has splenectomy in two patients (Wetherley-Mein, Jones and Pullan, I96I). In one of these two patients prednisolone did not have any effect on the hæmoglobin level.

In the patient reported here, prednisolone was given in an attempt to prolong the life-span of transfused red cells. In this it failed, but the redcell volume increased and the hæmoglobin level was maintained without transfusions for several months indicating increased red-cell production.

\section{Case Report}

The patient, a printer aged 52 years, was referred to the author's out-patient clinic at the Victoria Infirmary, Northwich, on May 2 I, 1962, with a history of increasing dyspnœa on exertion for a year. Others had noticed his pallor. His past history consisted of a duodenal ulcer in 1943, which had not bothered him since, and an operation for appendicitis and peritonitis in 1945 . There was no significant family history.

On examination he was very pale, there were no enlarged lymph nodes, and his chest, heart, blood pressure, central nervous system and urine were all normal. The spleen was enlarged and firm, reaching $5 \frac{1}{2}$ in. below the costal margin, but abdominal examination was otherwise negative.

Investigations. Three occult blood tests on the stools were negative. Blood picture: hæmoglobin $64 \%$ (100\% -14.5 g./100 ml.), colour index 0.9 , white cells $6,000 /$ $\mathrm{mm}^{3}$. with polymorphs $45 \%$, lymphocytes $53 \%$ and monocytes $2 \%$. An occasional blast cell was seen in the film and there was anisocytosis and poikilocytosis. Sternal puncture was attempted, but the bone was very hard and the needle could not be felt entering a marrow cavity. No marrow was obtained. X-rays of the pelvis and skull both showed osteosclerotic changes. An X-ray of chest showed clear lung fields, but osteosclerotic changes were seen in the ribs. An ECG was normal. There was no excess of urobilinogen in the urine. Splenic puncture showed predominantly lymphocytes, but also some polymorphs and normoblasts, the appearances being consistent with a diagnosis of myelofibrosis. No antibodies could be detected in the serum and a direct Coombs test was negative.

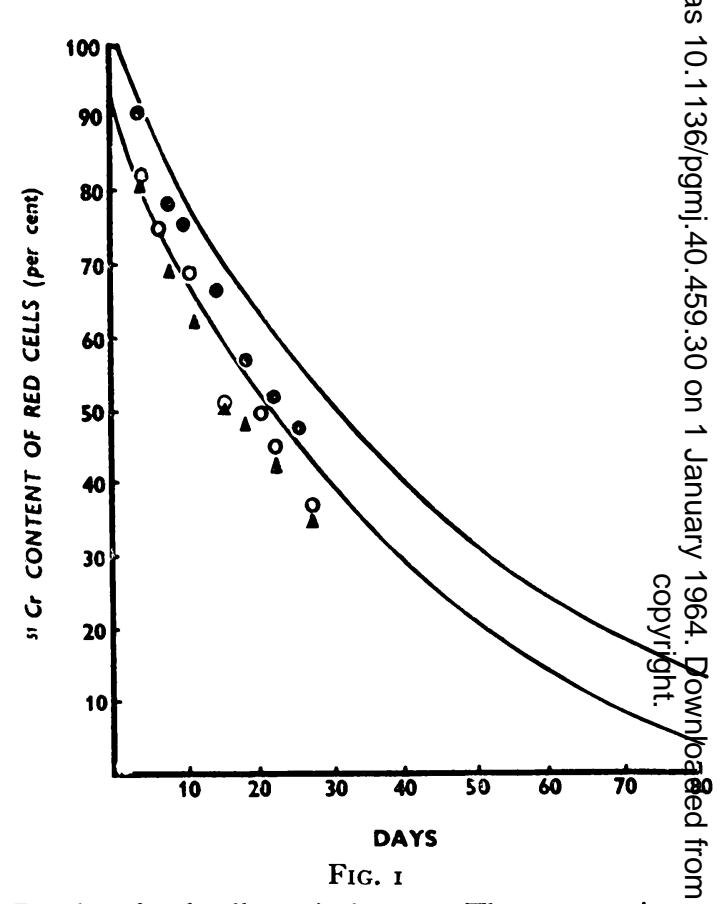

Results of red-cell survival tests.-The two continuoms lines indicate the 'normal range' of ${ }^{51} \mathrm{Cr}$ loss $\mathrm{fr}$ the red-cells (Pengelly and Wilkinson, 1962). The black dots represent the survival of the patienf's own red-cells. The open circles represent the fist survival test with tagged group $O R h-n e g a t$ isve red-cells and the black triangles the second rest with the same donor's red-cells while the patient was receiving prednisolone.

Progress and treatment. The patient remaifed reasonably well until August 1962. On August 16 tis hæmoglobin had dropped to $48 \%$ and thereafter he admitted to hospital from time to time for blood trañsfusions. His hæmoglobin was kept at about $60 \%$. Me received altogether 18 pints of blood during the period August 1962 to January 1963 . On January 9 his hær globin was $56 \%$ and the spleen had enlarged to pelvic brim. There had been no significant change in the white cells differential count or film appearanees. Prednisolone $10 \mathrm{mg}$. thrice daily was started andogo further transfusions were required until May 17 . \$n March I I methyltestosterone, Io mg. daily, was stared, but there was no apparent effect on the hæmoglobin level. From January 9 until May 6 the hæmoglobin remaiged at about $60 \%$. On May 6 it was $58 \%$. Unfortunatey, after this the patient became dyspnœic again and oon May 17 the hæmoglobin was $52 \%$. Transfusions vere 
started again, but on June 28 the hæmoglobin was only $36 \%$. The patient remains reasonably comfortable at the present time (August 1963) with a hæmoglobin of about $60 \%$.

Red-cell volume and survival studies. These were done with radioactive chromium $\left({ }^{51} \mathrm{Cr}\right)$ by the methods of Mollison and Veall (1955) applied as described by Pengelly and Wilkinson (1962). The first survival test was from August 5 until September 1, 1962. The curve (black dots in the figure) fell within the normal range (Pengelly and Wilkinson, r962). The initial red-cell volume was 1.581 and the final $\mathrm{r} .36 \mathrm{I}$.

The second survival test, using tagged group $O$ Rh-negative (cde) red cells, was from November 4 to December I, I962 (open circles in figure). When corrected by Method A (Mollison, 1956) the results indicated a mean red-cell life-span of about 60 to 65 days. The initial red-cell volume was $\mathrm{r} .65 \mathrm{I}$ and the final $\mathrm{r} .46 \mathrm{I}$. The same donor's red-cells were tested again after the start of the prednisolone therapy, from February 3 until March 2, 1963 (black triangles in figure). These results indicated a mean red-cell life-span of about 55 to 60 days. The initial red-cell volume was $I .48 I$ and the final I.54I. The compatibility of the donor's group $\mathrm{O}, \mathrm{Rh}$-negative red-cells was checked at the end of the final survival test and found to be quite satisfactory.

\section{Discussion}

It is evident from the results that the prednisolone had no beneficial effect on the life-span of the donor's group $\mathrm{O} R \mathrm{Rh}$ negative red-cells (figure), but at the same time there was an increase in the patient's red-cell volume and the hæmoglobin level did not fall for four months, despite the considerable transfusion requirements before the prednisolone was started. There must therefore have been an increase in the red-cell production from the functioning bone-marrow (if any) and/or the extramedullary hæmopoiesis in the liver and spleen. It was unfortunate that the remission did not last longer than about four months, but this is what might be expected in this progressive disease.

\section{Summary}

A patient with myelofibrosis is described in whom ${ }^{51} \mathrm{Cr}$ red-cell survival and volume studies showed red-cell production to be stimulated with prednisolone therapy. There was no evidence that the life-span of transfused red-cells was prolonged by this therapy. No blood transfusions were required for a period of four months whereas in the previous five months the patient had needed transfusions of I 8 pints to maintain a hæmoglobin level of about $60 \%$. Unfortunately the remission was only temporary.

My thanks are due to Dr. M. C. G. Israëls, Director of the Department of Clinical Hæmatology, Manchester Royal Infirmary, for the laboratory facilities; also to Dr. R. Ollerenshaw, Director of the Department of Medical Illustration, for the figure, and to the Board of Governors for a research grant.

\section{REFERENCES}

Bowdler, A. J., and Prankerd, T. A. J. (196I): Primary Myeloid Metaplasia, Brit. med. Y., r, 1352.

Britton, C. J. C. (1963): 'Whitby and Britton. Disorders of the Blood'. London: J. \& A. Churchill. Pp. 592 and 593 , 9th ed.

Gardner, F. H., and Pringle, J. C., Jun. (I96r): Androgens and Erythropoiesis: II. Treatment of Myeloid Metaplasia, New Engl. F. Med., 264, 103.

Mollison, P. L. (1956): 'Blood Transfusion in Clinical Medicine'. Oxford: Blackwell. 2nd ed., p. r39.

, and Veall, N. (I 955): The Use of Isotope ${ }^{51} \mathrm{Cr}$ as a Label for Red Cells, Brit. F. Hamat., $\mathbf{1}, 62$.

Pengelly, C. D. R., and Wilkinson, J. F. (1962): The Frequency and Mechanism of Hæmolysis in the Leukæmias, Reticuloses and Myeloproliferative Diseases, Ibid., 8, 343.

Szur, L., and Smith, M. D. (r96r): Red-cell Production and Destruction in Myelosclerosis, Ibid., 7, r47.

Wetherley-Mein, G., Jones, N. F., and Pullan, J. M. (196r): Effect of Splenectomy on Red-cell Production in Myelofibrosis, Brit. med. F., i, 84 .

Wintrobe, M. M. (1961): 'Clinical Hæmatology'. London: Henry Kimpton. 5th ed., p. 586. 